\title{
Korelasi antara Lama Menjalani Pengobatan Tuberkulosis Paru dengan Skor Depresi pada Pasien Tuberkulosis Paru yang Menjalani Pengobatan di Poliklinik Paru RSUD Dr. Pirngadi Medan
}

\author{
Masdiwani Noviana ${ }^{1}$, Ade Pryta Simaremare ${ }^{2}$, Rosminta Girsang ${ }^{3}$ \\ ${ }^{1}$ Mahasiswa Fakultas Kedokteran Universitas HKBP Nommensen \\ ${ }^{2}$ Departemen Mikrobiologi Fakultas Kedokteran Universitas HKBP Nommensen \\ ${ }^{3}$ Departemen IImu Kedokteran Jiwa Fakultas Kedokteran Universitas HKBP Nommensen \\ Korespondensi: Masdiwani Noviana, Email: masdiwani.noviana@yahoo.com
}

\begin{abstract}
Background: Pulmonary tuberculosis is an infectious disease caused by mycobacterium tuberculosis. This bactery can be transmitted through airbone particles and droplets. The treatment is a long term therapy and can be a stressor which effect patient's physical and psychologycal, that leads to depression.

Objective: The objective of this study was to determine the correlation between pulmonary tuberculosis treatment duration and depression score.

Methods: This study was a correlative analysis with cross sectional design. The sample were 52 respondents whom currently endured the treatment of pulmonary tuberculosis in pulmonary unit in RSUD Pirngadi Medan, selected by consecutive sampling. Beck's inventory depression II questionnaires were used to measure depression score. The data were analyzed with pearson correlation test.
\end{abstract}

Results: There was a low negative correlation between duration of pulmonary tuberculosis treatment and depression score $(p=0,027 ; r=-0,309)$.

Conclusion: The longer duration of pulmonary tuberculosis treatment, the lower the depression score.

Keywords: Pulmonary tuberculosis, pulmonary tuberculosis treatment, depression

\begin{abstract}
Abstrak
Latar belakang: Tuberkulosis paru adalah penyakit menular yang disebabkan oleh Mycobacterium tuberculosis. Penularannya dapat melalui udara dan percikan dahak. Tatalaksana tuberkulosis paru memerlukan waktu yang lama dan dapat menjadi stresor yang memiliki efek, baik kepada fisik maupun psikologi pasien yang menimbulkan depresi.
\end{abstract}

Tujuan: Tujuan penelitian ini untuk melihat bagaimana hubungan antara lama menjalani pengobatan tuberkulosis paru dengan skor depresi.

Metode: Penelitian ini merupakan penelitian analitik korelatif dengan desain potong lintang. Subjek sebanyak 52 orang pasien tuberkulosis paru yang menjalani pengobatan tuberkulosis paru di poliklinik paru RSUD. Dr Pirngadi Medan dipilih menggunakan teknik consecutive sampling. Kuesioner Beck's Depression Inventory II digunakan untuk mengukur skor depresi. Data dianalisis dengan uji korelasi pearson.

Hasil: Terdapat hubungan yang bermakna antara lama menjalani pengobatan tuberkulosis paru dengan skor depresi, dengan korelasi negatif yang lemah $(p=0,027 ; r=-0,309)$. 
Kesimpulan: Semakin lama menjalani pengobatan tuberkulosis paru, maka semakin rendah skor depresi.

Kata Kunci: Tuberkulosis paru, pengobatan tuberkulosis paru, depresi

\section{Pendahuluan}

Tuberkulosis paru adalah suatu penyakit infeksi menular, yang disebabkan oleh Mycobacterium tuberculosis yang dapat ditularkan melalui udara (airbone disease) atau melalui percikan dahak (droplet), sehingga orang-orang yang di sekitarnya mudah untuk terinfeksi jika penderita batuk, bersin, ataupun membuang ludah di sembarang tempat. ${ }^{1}$

Menurut Global TB Report 2018, pada tahun 2017 sebanyak 10 juta orang di dunia menderita tuberkulosis paru, di antaranya lakilaki 5,8 juta orang, perempuan 3,2 juta orang, serta anak-anak 1 juta orang. Indonesia berada diurutan ke-3 di dunia. ${ }^{2}$ Tahun 2018 tercatat jumlah populasi penderita tuberkulosis paru sebesar 161 kasus per 100.000 penduduk. ${ }^{3}$ Provinsi Sumatera Utara terletak pada urutan ke 5 yaitu 20.429 jiwa. Berdasarkan Profil Kesehatan Sumatera Utara Tahun 2018, angka kejadian tuberkulosis paru tertinggi berada di Kota Medan (36,45\%).4

Penderita tuberkulosis paru mengalami peningkatan karena beberapa faktor. Salah satunya adalah pengobatan yang tidak tuntas, yang berakibat pengobatan menjadi lebih lama lagi. Normalnya, pengobatan memerlukan waktu 6 - 8 bulan dengan menggunakan Obat Anti Tuberculosis (OAT). Lama pengobatan dan banyaknya jumlah obat yang dikonsumsi tiap harinya pada pasien tuberkulosis paru selain menimbulkan permasalahan seperti komplikasi penyakit, juga dapat menimbulkan reaksi psikologis yang dapat mengganggu pengobatan. Rekasi psikologis itu dapat berupa gangguan emosi, perubahan mood yang signifikan, stres, kecemasan dan gangguan depresi.., 6

Resiko terjadinya depresi diperburuk oleh masalah sosial atau hubungan dengan masyarakat, dan buruknya tingkat kesehatan yang dirasakan penderita. Penderita tuberkulosis paru sering dipersepsikan oleh masyarakat sebagai sumber infeksi dan merupakan penyakit berbahaya serta adanya penolakan sosial dalam kehidupan masyarakat serta adanya isolasi terhadap penderita tuberkulosis paru dapat mengakibatkan penurunan kesejahteraan psikososial dalam jangka panjang. ${ }^{?}$

Bebarapa penelitian menunjukkan bahwa ada hubungan lama pengobatan tuberkulosis paru dengan tingkat stressor dan semakin lama pengobatan tuberkulosis paru maka semakin berat tingkat stressor nya. ${ }^{8}$ Namun penelitian yang dilakukan Marselia menyatakan terdapat hubungan lama pengobatan tuberkulosis paru dengan tingkat depresi dan semakin lama pengobatan tuberkulosis paru maka semakin menurun. ${ }^{9}$

Tujuan dilakukan penelitian ini adalah untuk mengetahui bagaimana korelasi antara lama menjalani pengobatan dengan skor depresi pada pasien tuberkulosis paru yang menjalani pengobatan.

\section{Hasil}

Dari hasil karakteristik jenis kelamin, usia, pekerjaan dan pendidikan yang dilakukan terhadap 52 sampel, didapatkan hasil yang menjalani pengobatan tuberkulosis paru lebih banyak berjenis kelamin laki-laki sebanyak 36 orang $(69,2 \%)$ dan berumur dibawah 50 tahun yaitu sebanyak 29 orang $(55,8 \%)$. Bila dilihat dari status pekerjaan dalam subjek penelitian ini paling banyak yang berstatus tidak bekerja yaitu sebanyak 23 orang $(44,2 \%)$, sedangkan pendidikan terakhir subjek dalam penelitian ini yang terbanyak adalah SMA, sebanyak 26 orang (50\%).

\section{Tabel 1. Tabel Deskripsi Karakterisktik Subjek Penelitian}

\begin{tabular}{lrr}
\hline Karakteritik & $\begin{array}{c}\mathbf{n} \\
\text { (orang) }\end{array}$ & \multicolumn{1}{c}{$\%$} \\
\hline Jenis Kelamin & 36 & 69,2 \\
Laki-laki & 16 & 30,8 \\
Perempuan & & \\
Usia & 29 & 55,8 \\
$<50$ Tahun & 23 & 44,2 \\
$\geq 50$ Tahun & & \\
Status Pekerjaan & 23 & 44,2 \\
Tidak Bekerja & 6 & 11,5 \\
Wiraswasta & 15 & 28,8 \\
Pegawai Swasta & 4 & 7,7 \\
PNS & 1 & 1,9 \\
Petani & 3 & 5,8 \\
Buruh Bangunan & & \\
Pendidikan Terakhir & 5 & 9,6 \\
SD & 12 & 23,1 \\
SMP/SLTP & 16 & 50,8 \\
SMA/SLTA & 19 & 17,3 \\
Perguruan Tinggi Swasta & & \\
\hline
\end{tabular}

Tabel 2. Tabel Rerata Lama Menjalani pengobatan Tuberkulosis Paru dan Rerata Skor Depresi

\begin{tabular}{lrcc}
\hline \multicolumn{1}{c}{ Variabel } & Rerata & SD & $\boldsymbol{p}^{*}$ \\
\hline Lama menjalani pengobatan & 3,59 & 1,774 & 0,053 \\
tuberkulosis paru (bulan) & 20,94 & 6,056 & 0,200 \\
Skor depresi &
\end{tabular}

${ }^{*}$ nilai probabilitas dengan uji Kolmogorov-Smirnov

Tabel 3. Tabel Rerata Lama Menjalani pengobatan Tuberkulosis Paru dan Rerata Skor Depresi

\begin{tabular}{lcc}
\hline & Skor \\
& depresi \\
\hline Lama Menjalani Pengobatan Tuberkulosis Paru & $r$ & $-0,309$ \\
& $p$ & 0,027 \\
& $n$ & 52 \\
\hline
\end{tabular}

* Uji korelasi Pearson

Rerata lama menjalani pengobatan tuberkulosis paru pada subjek penelitian ini adalah sebesar 4 bulan, dan rerata skor depresi subjek penelitian yaitu sebesar 21 .

Pada penelitian ini dilakukan analisis korelasi lama menjalani pengobatan tuberkulosis paru dengan skor depresi menggunakan uji hipotesis korelatif. Sebelumnya dilakukan uji normalitas Kolmogorov-smirnov. Karena data terdistribusi normal, maka uji 
hipotesis yang dilakukan adalah uji korelasi Pearson. Hasil analisis menunjukkan terdapat korelasi negatif dengan kekuatan korelasi lemah antara lama menjalani pengobatan tuberkulosis paru dan skor depresi.

\section{Pembahasan}

Penelitian yang dilakukan terhadap 52 orang ini mendapatkan korelasi yang bermakna antara lama menjalani pengobatan tuberkulosis paru dan skor depresi. Nilai korelasi Pearson sebesar $-0,309$ menunjukkan korelasi tersebut bersifat negatif dan lemah. Hal ini menunjukkan bahwa semakin lama masa pengobatan tuberkulosis paru, maka skor depresinya semakin rendah.

Penelitian yang dilakukan oleh Ashari Zuprin pada tahun 2015 di Banda Aceh mendapatkan hasil yang sejalan dengan penelitian ini. ${ }^{10}$ Responden dalam penelitian Zuprin yang telah lama menjalani pengobatan tuberkulosis paru cenderung memiliki tingkat depresi yang lebih rendah, dibanding dengan responden yang baru menjalani pengobatan. Hal ini disebabkan karena semakin lama seseorang menjalani pengobatan tuberkulosis paru, maka ia akan menjadi semakin adaptif. Penelitian yang dilakukan oleh Reni et al pada tahun 2016 di Pontianak juga menunjukkan hasil yang sama. menunjukkan ada hubungan lama pengobatan tuberkulosis paru dengan dukungan keluarga pasien. Semakin lama pasien menjalani pengobatan, maka pasien semakin bisa beradaptasi dan dapat mengatasi masalah (stressor) yang timbul. ${ }^{9}$ Pasien tuberkulosis paru cenderung mengalami syok saat pertama kali terdiagnosis tuberkulosis paru. Semakin lama menjalani pengobatan tuberkulosis paru, pasien akan beradaptasi dengan situasi ini. dukungan dan motivasi dari keluarga dan masyarakat sekitar yang sangat membantu bagaimana pasien dapat beradaptasi dan mengurangi depresi yang mereka alami. ${ }^{9}$

Tuberkulosis paru mempunyai mediator terhadap mycobacterium tuberculosis (interleukin 1a dan $\beta$ (IL-1a dan IL-1 $\beta$ ), tumor nekrosis faktor- $\alpha$ (TNF-a) dan interleukin-6 (IL-6)). Mediator tersebut tidak hanya sebagai respon terhadap inflamasi lokal namun juga mengganggu keseimbangan triptofan di dalam plasma, dimana akan membuat kadar serotonin juga menurun, inilah yang membuat pasien tuberkulosis paru sangat rentan terhadap depresi. ${ }^{12}$ OAT Lini pertama (Isoniazid) merupakan senyawa turunan hidrazin, golongan Monoamin Oksidase Inhibitor (MAols) yang memiliki peran sebagai antidepresan, jika pasien tuberkulosis paru patuh mengkonsumsi obat secara teratur maka jumlah mycobacterium tuberculosis akan berkurang kemudian sitokin pro inflamasi juga akan berkurang, sintesis serotonin akan mulai berlangsung normal dan dapat melakukan tugasnya untuk mengaktifkan neuro pascasinaps hingga akhirnya gejala depres akan hilang seiring seimbangnya kadar serotonin dalam sinaps. ${ }^{13}$

\section{Kesimpulan}

Dari hasil penelitian dapat disimpulkan bahwa terdapat korelasi negatif dengan kekuatan korelasi yang lemah antara lama menjalani pengobatan tuberkulosis dengan skor depresi. Semakin lama menjalani pengobatan tuberkulosis paru, maka semakin rendah skor depresi pasien yang menjalani pengobatan tuberkulosis paru.

\section{Daftar Pustaka}

1. Depkes. Tuberkulosis [Internet]. 2017. Tersedia pada: https://depkes.go.id

2. WHO. Global tuberculosis report [Internet]. 2018. Tersedia pada: https://www.who.int/tb/publications/global_report/en/

3. Indah M. Infodatin tuberkulosis [Internet]. 2018. Tersedia pada: http://www.depkes.go.id/resources/download/pusdatin/infodatin/infodatin tuberkulosis 2018.pdf

4. Dinas Kesehatan Provinsi Sumatera Utara. Profil Kesehatan Provinsi Sumatera Utara tahun 2017. Medan: GERMAS; 2018. 104 hal.

5. Rochman B, Rihadini, Budhiarti E. Pengaruh depresi terhadap kepatuhan minum OAT pada penderita TB. J Kedokt Muhammadiyah. 2014;3(2):1-8.

6. Mustaqin, Suryawati, Priyanto H. Hubungan tingkat kepatuhan minum obat anti tuberkulosis dengan gejala depresi pada pasien tuberkulosis paru di RSUDZA Banda Aceh. J Ilm Mhs Kedokt Medisia. 2017;2(4):13.

7. Nahda ND, Kholis FN, Wardani ND, Hardian. Faktor-faktor yang berpengaruh terhadap kejadian depresi pada pasien tuberkulosis di RSUP Dr. Kariadi Semarang. J Kedokt Diponegoro [Internet]. 2017;6(4):1530-1. Tersedia pada: https://ejournal3.undip.ac.id/index.php/medico/article/viewFile/18383/1746 3

8. Chilyatiz Zahro S. Hubungan lama pengobatan TBC dengan tingkat stres penderita TBC di Puskesmas Tambelangan Kabupaten Sampang. J IIm Kesehat [Internet]. 2016;9:142-4. Tersedia pada: https://journal2.unusa.ac.id/index.php/JHS/article/view/175

9. Marselia R, Wilson, Pratiwi SE. Hubungan antara lama terapi terhadap tingkat gejala depresi pada pasien tuberkulosis paru di Unit pengobatan Penyakit Paru-Paru Pontianak. J Cerebellum [Internet]. 2017;3(3):2. Tersedia pada: http://jurnal.untan.ac.id/index.php/jfk/article/download/24529/75676576107

10. Zuprin A. Hubungan lama pengobatan tuberkulosis dengan tingkat gejala depresi pada pasien tuberkulosis paru di RSUD DR.Zainoel Abidin Banda Aceh. J Kedokt Univ Syah Kuala. 2015;30.

11. Sandock, Benjamin J, Sandock, Virginia A HM. Kaplan dan Sadock Buku Ajar Psikiatri. 2 ed. Jakarta: EGC; 2010. 213 hal.

12. Dantzer R, O C, Freud G, Johnson R, Kelley K. Inflammation to sickness and depression: when the immune system subjugates the brain. Pubmed. 2018;46-56

13. Guyton A, Hall J. Buku Ajar Fisiologi Kedokteran. 12 ed. Jakarta: Kedokteran EGC; 2011. 412 hal. 